\title{
Cancer chemotherapy based on targeting of cytotoxic peptide conjugates to their receptors on tumors
}

\author{
Andrew V Schally and Attila Nagy \\ Section of Experimental Medicine, Department of Medicine, Tulane University School of Medicine, New Orleans, Louisiana 70112-2699, USA and \\ Endocrine, Polypeptide and Cancer Institute, Veterans Affairs Medical Center, New Orleans, Louisiana 70112-1262, USA \\ (Correspondence should be addressed to A V Schally, Veterans Affairs Medical Center, 1601 Perdido Street, New Orleans, Louisiana 70112-1262, \\ USA)
}

\begin{abstract}
In view of non-specific toxicity of most chemotherapeutic agents against normal cells, the development of targeted chemotherapy is warranted. Efficient targeting of chemotherapeutic drugs to the cancerous area could be of great benefit for patients with advanced or metastatic tumors. Targeted cytotoxic peptide conjugates are hybrid molecules composed of a peptide carrier which binds to receptors on tumors and a cytotoxic moiety. New cytotoxic analogs of LHRH, AN-152 in which doxorubicin (DOX) is linked to [D-Lys $\left.{ }^{6}\right] \mathrm{LHRH}$, and AN-207 which consists of 2-pyrrolino-DOX (AN-201) coupled to the same carrier, show high-affinity binding and are much less toxic and more effective in vivo than their respective radicals in inhibiting tumor growth in LHRH receptor-positive models of human ovarian, mammary, or prostatic cancer. These results suggest that targeted cytotoxic LHRH analogs such as AN-207 could be considered for treatment of these cancers. The presence of receptors for bombesinlike peptides on a wide variety of tumors prompted us to use some of our bombesin/gastrin-releasing peptide antagonists as carrier molecules. Cytotoxic bombesin analogs, such as AN-215 containing AN201, might find application in the treatment of small cell lung carcinoma (SCLC), and colorectal, gastric, pancreatic, mammary, and prostatic cancers. Since somatostatin receptors are found in various human neoplasms and the receptor subtypes to which octapeptide analogs bind with high affinity have been identified, we synthesized several cytotoxic somatostatin analogs including AN-162 and AN-238 containing DOX and 2-pyrrolino-DOX respectively, linked to octapeptide RC-121. Cytotoxic somatostatin analog AN-238 efficaciously inhibits growth of human breast or prostate cancers expressing somatostatin receptors- 2 and -5 and can be used for receptor-targeted chemotherapy. Cytotoxic somatostatin analogs might also find applications for the therapy of human pancreatic, colorectal, and gastric cancer as well as brain tumors and non-SCLC. Cytotoxic compounds linked to analogs of hormonal peptides like LHRH, bombesin, and somatostatin that can be targeted to certain tumors possessing receptors for those peptides could be an important addition to oncological armamentarium.
\end{abstract}

European Journal of Endocrinology 141 1-14

\section{Introduction}

For more than five decades, chemotherapy has been the main modality for systemic treatment of advanced or metastatic cancers $(1,2)$. Cytotoxic drugs are used as single agents or as combinations of several antitumor agents with different mechanisms of action $(1,2)$. Chemotherapy can also be applied as adjuvant to surgical resection and radiotherapy $(1,2)$. Cancer chemotherapy is limited by intrinsic or acquired multidrug resistance of tumor cells and toxicity to normal cells (1-3). Although the effectiveness of chemotherapy can be increased by escalating the doses, the option for dose elevation is always restricted by the toxicity of chemotherapeutic drugs (1-3). A more selective delivery of the cytotoxic agents to the primary tumors and their metastases would allow a dose escalation and reduce the peripheral toxicity (3).

One hundred years ago, after detecting the specificity of antigen-antibody interactions, Paul Ehrlich created the concept of a 'magic bullet' for cancer therapy consisting of a molecule selective for a targeted cell that was linked to a highly toxic group (Fig. 1) (4). Thus, based on the assumption that tumors possess specific antigens, Ehrlich conceived the idea that antibodies could deliver toxic compounds to tumor cells and eradicate them (4). Ten years later, in 1908, Paul Ehrlich received the Nobel Prize in Medicine in recognition for his work on immunity and not for the concept of 'magic bullets'. The idea of 'magic bullets' 


\begin{tabular}{||c||}
\hline \hline "Bodies which possessed a particular \\
affinity for a certain organ...as a carrier \\
by which to bring therapeutically active \\
groups to the organ in question." \\
P. Ehrlich (1898) \\
\hline
\end{tabular}

Figure 1 From the writings of Paul Ehrlich (4) and Collected Studies on Immunity, vol. 2, pp 442-447. New York: Wiley Press, 1906.

made a major impact on medicine and chemistry, but remained essentially unexplored for many decades. With the advent of monoclonal antibodies (5) which recognize antigens associated with many types of human cancer, important advances in targeted therapy were made $(6,7)$. The 'magic bullet' approach was used for the construction of monoclonal antibody-toxin conjugates called immunotoxins and other chimeric toxins (7-9). These complexes consisted of cell-binding proteins, particularly monoclonal antibodies or growth factors like epidermal growth factor (EGF), conjugated to various toxins of bacterial or plant origin. These toxins included Pseudomonas exotoxin, diphtheria toxin, and ricin which act by irreversibly arresting the synthesis of protein in eukaryotic cells $(8,9)$. The highly specific antibodies deliver toxins into the cell, where they exert their cytotoxic effects. EGF, interleukins, and other growth factors or hormones coupled to toxins can also kill cells having respective receptors and induce remission of tumors (8-10). Initially, immunotoxins and chimeric toxins were made by chemically coupling antibodies or receptor-binding proteins to toxins but, more recently, recombinant DNA technology has been used $(8,9)$. Similarly, doxorubicin (DOX) and other chemotherapeutic agents can also be conjugated to monoclonal antibodies which recognize antigens expressed on human cancers or to growth factors (11). Thus, it is now well established that chemotherapeutic compounds and toxins can be covalently attached to various carriers, including hormones, for which receptors are present on cancer cells or to antibodies that preferentially recognize tumor cells (6-12). Such conjugates are designed to deliver cytotoxic agents more selectively to cancer cells. Ideally, tumor cells that bind these conjugates would be killed while normal cells that do not have the receptors would be spared (12).

\section{Hormonal chemotherapeutic agents}

The first hormonally targeted chemotherapeutic agents developed for the treatment of prostate cancer and breast cancer used estrogenic steroid molecules as carriers for various alkylating agents $(13,14)$. Nitrogen mustard compounds were chemically coupled to carrier estrogens for enhancing selectivity and cytotoxicity on estrogen receptor-positive cells $(13,14)$. The cytotoxic estrogens, such as estracyte (estramustine), accumulate in the rat prostate due to the presence in the ventral lobe of the prostate of a protein that binds estramustine with high affinity and high capacity (13, 14). However, estramustine has low affinity for the conventional estrogen receptors. Estracyte has been used clinically in patients with hormone refractory prostate cancer and in women with advanced carcinoma of the breast, but objective response rates are low. However, the use of other hormonal carriers that could increase the efficacy of chemotherapeutic agents appeared to be worthy of extensive exploration.

In other early studies, alkylating agents of the nitrogen mustard type, such as chlorambucil (Chl) and melphalan were incorporated into several peptide hormones, including bradykinin (15), luteinizing hormone (LH)-releasing hormone (LHRH) (16), and angiotensin II (17). Such analogs were expected to bind irreversibly to the receptors, producing a sustained blockade. However, incorporation of chlorambucil into fragments of bradykinin and related peptides did not produce an irreversible inhibitor of bradykinin receptors (15). Similarly, [Chl-D-Phe $\left.{ }^{1}, \mathrm{D}-\mathrm{Phe}^{2}, \mathrm{D}-\mathrm{Trp}^{3,6}\right] \mathrm{LHRH}$ showed much less antagonistic activity than the nonalkylating Ac-D-Phe ${ }^{1}$ analog (16), and [D-Lys(Chl) $\left.{ }^{6}\right] \mathrm{LHRH}$ had agonistic and not antagonistic activity. One of the early conjugates containing DNA intercalator anthracyclins was reported by Varga (18). In this conjugate, daunomycin was linked to the N-terminal amino group of aspartic acid and $\varepsilon$-amino groups of Lys residues in $\beta$-melanocyte-stimulating hormone. The conjugate was able to kill melanoma cells in vitro (18).

Our interest in developing cytotoxic peptides arose more than 10 years ago (12). The 'magic bullet' approach was utilized by us for the synthesis of a large number of cytotoxic analogs of hypothalamic peptides $(12,19-22)$. These consisted of diverse hormonal analogs, mostly of LHRH, conjugated to a variety of chemotherapeutic agents. The high specificity of peptide receptors was utilized in an attempt to deliver these agents to the tumor cells where they might exert their cytotoxic effects (19-22). It was hoped that such hybrids could selectively destroy classes of cells containing specific receptors for several peptide hormones found on various cancer cells and serve as specific therapeutic agents for cancer treatment (12). The development of targeted hybrids directed against specific cell membrane receptors has been an extremely active area of our research. Earlier phases of this work were reviewed previously (12). Recent advances in the synthesis and evaluation of cytotoxic peptides in our laboratory may make it possible to put the concept of 'magic bullets' on firm foundations. These studies are described herein. 


\section{Cytotoxic LHRH analogs}

\section{Receptors for LHRH}

Agonistic analogs of LHRH have been widely used in oncology and gynecology for nearly two decades (reviewed in references 23-26). Modern LHRH antagonists like Cetrorelix became clinically available more than 5 years ago, have been evaluated in various oncological and gynecological trials, and are awaiting regulatory approval $(23,25,26)$. The mechanism of action of both agonistic and antagonistic analogs is mainly based on the inhibition of pituitary and gonadal functions $(23,24)$, and medical castration produced by chronic administration of LHRH analogs accounts for most benefits derived from the treatment (24). However, there are also many findings indicating that LHRH agonists and antagonists exert direct effects on tumor cells (23). The evidence for direct action of LHRH analogs on tumors is based on clinical results, the detection of high-affinity binding sites for LHRH in various cancers, and the inhibitory effects of analogs on tumor cell lines in cultures (for reviews see 23, 24, 27). Specific membrane receptors for LHRH have been found in various animal and human cancers $(23,24,28)$. Thus, high-affinity binding sites for LHRH are present in most human prostate cancer samples (29-31). Receptors for LHRH were also detected in PC-82, LNCaP, and DU-145 human prostate cancer lines and Dunning rat prostate cancers (29-33). The expression of mRNA for LHRH receptors was also found in PC-82, DU-145 and LNCaP tumors and in most human prostate cancer specimens $(31,33,34)$. Several investigators reported the presence of LHRH receptors in various human mammary carcinoma cell lines including MCF-7 and MDA-MB-231 (35-37). We detected high-affinity LHRH binding sites in more than $50 \%$ of human breast cancer samples (38). LHRH receptors were similarly found in about $80 \%$ of human ovarian epithelial cancer specimens and in EFO-21 and EFO27 , and OV-1063 human ovarian cancer lines $(24,27$, 39-41). In nearly $80 \%$ of human endometrial carcinomas (42) and in HEC-1A and Ishikawa endometrial cancer lines, the presence of high-affinity membrane receptors for LHRH was also established $(24,27,43)$. LHRH receptors on human cancers appear to be similar to pituitary LHRH receptors (44). The expression of LHRH receptor gene in human breast, endometrial, and ovarian tumors and respective cancer cell lines was also demonstrated by RT-PCR using the specific human LHRH receptor primers $(27,40,44,45)$. These findings provided support for the development of chemotherapy targeted to LHRH receptors on tumors and a rationale for the use of approaches based on cytotoxic LHRH analogs in malignancies in which specific receptors for LHRH are found. Thus, on the basis of the presence of specific receptors for LHRH on tumor cells, we started development of a new class of targeted antitumor agents by linking various cytotoxic radicals to LHRH analogs.

\section{Design and synthesis of targeted cytotoxic analogs of LHRH}

It was revealed many years ago that substitution of the Gly amino acid residue at position 6 of LHRH (pyroGlu-His-Trp-Ser-Tyr-Gly-Leu-Arg-Pro-Gly$\mathrm{NH}_{2}$ ) by various D-amino acids results in very potent analogs of LHRH with high binding affinity (46). In our early attempts to create cytotoxic analogs of LHRH, D-melphalan (D-3-\{p-[bis(2-chloroethyl)amino]phenyl $\}$ alanine), an alkylating nitrogen mustard derivative of D-phenylalanine, was incorporated at position 6 of LHRH (19). This cytotoxic LHRH analog showed binding affinity to rat pituitary, human breast and prostate cancer and rat Dunning prostate tumor cell membranes similar to that of the superactive LHRH agonist [D-Trp ${ }^{6}$ ]LHRH (19). Antagonistic analogs containing Ac-D-Nal $(2)^{1}, \mathrm{D}-\mathrm{Phe}(\mathrm{pCl})^{2}, \mathrm{D}-\mathrm{Pal}(3)^{3}$ or $\mathrm{D}^{3} \mathrm{Trp}^{3}$, $\mathrm{Arg}^{5}{ }^{\mathrm{D}} \mathrm{D}-\mathrm{Mel}^{6}$ and $\mathrm{D}-\mathrm{Ala}^{10}$ substitutions were also produced (19). Interestingly, the analog containing D-Trp ${ }^{3}$ substitution displayed very low binding affinity to receptors for LHRH while its counterpart with D-Pal $(3)^{3}$ showed very high binding affinity (19). Among the numerous synthetic agonistic and antagonistic analogs of LHRH, those having a D-Lys moiety at position 6 offer an amino side-chain for convenient attachment of various cytotoxic compounds. It turned out that even bulky molecules could be linked to the $\varepsilon$-amino group of the ${ }^{2}-\mathrm{Lys}^{6}$ moiety without significant loss of the high binding affinity of the peptide portion to receptors for LHRH. This bulk tolerance was exploited in our attempts to create cytotoxic LHRH hybrids in which diverse cytotoxic radicals were attached covalently to the D-Lys side-chain of the LHRH carrier agonists or antagonists $(21,47)$. The cytotoxic compounds included alkylating agent melphalan, DNA strandbreaker cross-linking agent cisplatin, antimetabolite methotrexate and anthracycline derivative 2-(hydroxymethyl)anthraquinone. Complexes of heavy metals such as $\mathrm{Cu}$ and $\mathrm{Zn}$ were also incorporated by sophisticated chemistry (20). In some of these early conjugates, DNA intercalating antibiotic doxorubicin (DOX), the most widely used anticancer agent, was linked to LHRH analogs using a glutaric acid spacer which formed carboxamide bonds between the daunosamine nitrogen of DOX and the $\varepsilon$-amino group of the D-Lys ${ }^{6}$ moiety of the carrier (21). Unfortunately, the antiproliferative activity of DOX within these hybrids was greatly reduced due to the modification by the linkage. However, DOX can be linked by various chemical reactions to macromolecular carriers without a severe loss of its antitumor activity. Some noteworthy approaches include the sodium periodate oxidation followed by reductive alkylation at the daunosamine 
sugar moiety (48), the use of spacer arms that are acidsensitive (lysosomotrop) $(49,50)$ or enzyme-sensitive (51). The formation of ester bonds and C-N linkages between 14-bromodaunorubicin and proteins or poly-Lamino acids has also been reported to result in conjugates with preserved cytotoxic activity $(52,53)$. Since 14-O-esters of DOX are stable and known to have similar antitumor effects to DOX, we prepared N-FmocDOX-14-O-hemiglutarate which was in turn coupled to the D-Lys side-chain of the LHRH analog carriers (54). The cytotoxic hybrids obtained after deprotection fully preserved the in vitro cytotoxicity of DOX and the binding affinity of the LHRH carriers.

Because the daunosamine moiety of DOX is intact in conjugates containing DOX-14-O-hemiglutarate, we developed several daunosamine-modified derivatives of DOX that could be linked to the carriers by the same chemistry. Our efforts led to the development of a new derivative of DOX, 2-pyrrolino-DOX (AN-201), which is 500-1000 times more active in vitro than its parent compound (55). To form this analog, DOX was reacted with a 30-fold excess of 4-iodobutyraldehyde in dimethylformamide. The conversion of DOX to 2pyrrolino-DOX is virtually $100 \%$ and takes place within minutes. The same reaction could be utilized for the conversion of LHRH analogs containing DOX to the corresponding analogs with AN-201 (54). Thus, AN152 in which DOX is linked to [D-Lys ${ }^{6}$ LHRH was reacted with a 30-fold excess of 4-iodobutyraldehyde in dimethylformamide and converted in a high yield to superactive

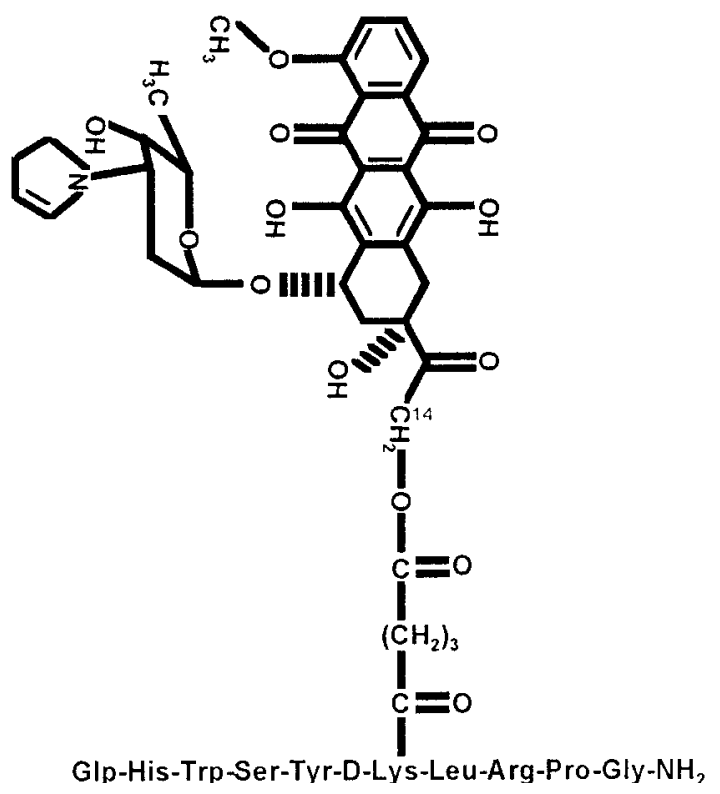

Figure 2 Molecular structure of cytotoxic LHRH analog AN-207. [D-Lys ${ }^{6}$ ]LHRH is linked through the $\varepsilon$-amino group of its D-Lys moiety and a glutaric acid spacer to the 14-OH group of 2-pyrrolinoDOX (AN-201) (54) Copyright (1996) National Academy of Sciences, USA. This figure is reprinted with permission from Proceedings of the National Academy of Sciences of the USA analog AN-207 containing 2-pyrrolino-DOX (Fig. 2). Both the antiproliferative activity of the cytotoxic radicals and the high binding affinity of the carrier to LHRH receptors are fully preserved in the cytotoxic LHRH analogs $\mathrm{AN}-152$ and $\mathrm{AN}-207$ (54). In vitro, in MCF-7 human breast cancer line and MXT estrogenindependent mouse mammary carcinoma line, the cytotoxic activities of AN-152 and AN-207 corresponded to those of DOX and AN-201 respectively (54). However, DOX and AN-152 were cytotoxic at $10^{-7} \mathrm{~mol} / \mathrm{l}$ concentrations while $\mathrm{AN}-207$ and $\mathrm{AN}-201$ were effective at much lower concentrations of $3 \times 10^{-10} \mathrm{~mol} / \mathrm{l}$ (54). These new cytotoxic analogs of LHRH, AN-152 and AN-207 showed high-affinity binding to membranes of human breast cancer specimens and MCF-7 and MDAMB-231 human breast cancer cell lines displaying $\mathrm{IC}_{50}$ values in nanomolar concentration range $\left(\mathrm{IC}_{50}=2-\right.$ $13 \mathrm{nmol} / \mathrm{l})(45)$.

\section{Oncological tests in vivo on cytotoxic LHRH analogs}

In an early in vivo study, rats bearing Dunning R-3327-H prostate adenocarcinomas were treated with prototypes of hybrid cytotoxic LHRH analogs containing anthraquinone or methotrexate (56). Large doses of these early cytotoxic analogs had moderate antitumor effects and caused a slightly greater tumor growth inhibition than the carrier peptide alone. Free anthraquinone or methotrexate given in equimolar doses were ineffective (56). Various cytotoxic LHRH analogs were also shown to inhibit the growth of estrogen-dependent and -independent MXT mouse mammary carcinoma in vivo (57). Because relatively large doses were used, it is likely that earlier cytotoxic LHRH analogs inhibited tumor growth by a combined hormonal and cytotoxic action $(56,57)$.

\section{Ovarian cancer}

In an initial in vivo study with the new cytotoxic analog AN-152, we demonstrated that the conjugate given intraperitoneally was more effective and less toxic than equimolar doses of DOX in the treatment of LHRH receptor-positive OV-1063 human ovarian cancers in nude mice (41). The growth of OV-1063 ovarian tumors in nude mice was inhibited significantly 4 weeks after treatment with $\mathrm{AN}-152$ as based on reduction in tumor volume, even at the lowest dose tested $(20.6 \mu \mathrm{mol} / \mathrm{kg})$; the toxic effects of an equivalent dose of DOX caused substantial mortality (41) (Table 1). High-affinity receptors for LHRH and EGF were found on cell membranes of OV-1063 cancers; however, after in vivo treatment with $\mathrm{AN}-152$, LHRH receptor-binding sites were not detectable and EGF receptors were reduced in number (41). AN-152 did not inhibit the growth of LHRH receptor-negative UCI-107 human ovarian carcinoma in nude mice. This indicates that 
Table 1 Effects of cytotoxic LHRH conjugates AN-152 and AN-207 as well as their respective cytotoxic radicals DOX and 2-pyrrolino-DOX (AN-201) on various human and rodent LHRH receptor-positive tumors.

\begin{tabular}{|c|c|c|c|c|c|}
\hline & \multirow{2}{*}{$\begin{array}{l}\text { Ovarian cancer } \\
\text { OV-1063 } \\
\text { (human) }^{1}\end{array}$} & \multicolumn{2}{|c|}{ Breast cancers } & \multicolumn{2}{|c|}{ Prostate cancers } \\
\hline & & $\begin{array}{c}\mathrm{MXT} \\
\text { (mouse) }\end{array}$ & $\begin{array}{c}\text { MX-1 } \\
\text { (human) }^{1}\end{array}$ & $\begin{array}{l}\text { Dunning R-3327-H } \\
\text { (rat) }\end{array}$ & $\begin{array}{l}\text { PC-82 } \\
\text { (human) }^{1}\end{array}$ \\
\hline \multicolumn{6}{|l|}{$\mathrm{AN}-152$} \\
\hline Dose & $\begin{array}{l}20.6 \mu \mathrm{mol} / \mathrm{kg} \text { once, } \\
\text { i.p. }\end{array}$ & $\begin{array}{l}35.5 \mu \mathrm{mol} / \mathrm{kg} \text { once, } \\
\text { i.p. }\end{array}$ & Not tested & Not tested & Not tested \\
\hline Effect & $\begin{array}{l}\text { Powerful } 84 \% \text { growth } \\
\text { inhibition }\end{array}$ & $\begin{array}{l}\text { Powerful 98\% growth } \\
\text { inhibition }\end{array}$ & & & \\
\hline Toxicity & No side-effects & 1 of 5 animals died & & & \\
\hline \multicolumn{6}{|l|}{ DOX } \\
\hline Dose & $\begin{array}{c}20.6 \mu \mathrm{mol} / \mathrm{kg} \text { once } \\
(12 \mathrm{mg} / \mathrm{kg}) \text { i.p. }\end{array}$ & $\begin{array}{l}35.5 \mu \mathrm{mol} / \mathrm{kg} \text { once, } \\
\text { i.p. }\end{array}$ & Not tested & Not tested & Not tested \\
\hline Effect & Not significant & $\begin{array}{l}\text { Powerful 94\% growth } \\
\text { Inhibition }\end{array}$ & & & \\
\hline Toxicity & 6 of 9 animals died & 5 of 5 animals died & & & \\
\hline \multicolumn{6}{|l|}{ AN-207 } \\
\hline Dose & $\begin{array}{l}150 \mathrm{nmol} / \mathrm{kg} \text { twice, } \\
\text { i.p. }\end{array}$ & $\begin{array}{l}110 \mathrm{nmol} / \mathrm{kg} \text { twice, } \\
\text { i.p. }\end{array}$ & $\begin{array}{l}250 \mathrm{nmol} / \mathrm{kg} \text { once, } \\
\text { i.v. }\end{array}$ & $\begin{array}{l}50 \mathrm{nmol} / \mathrm{kg} \text { three } \\
\text { times, i.p. }\end{array}$ & $\begin{array}{l}200 \mathrm{nmol} / \mathrm{kg} \text { once, } \\
\text { i.v. }\end{array}$ \\
\hline Effect & $\begin{array}{l}\text { Significant growth } \\
\text { inhibition }\end{array}$ & $89 \%$ growth inhibition & $\begin{array}{l}10 \text { of } 10 \text { animals } \\
\text { cured }\end{array}$ & All tumours regressed & $\begin{array}{l}\text { Significant growth } \\
\text { inhibition }\end{array}$ \\
\hline Toxicity & No side-effects & 1 of 10 animals died & $\begin{array}{l}\text { Transient fall in } \\
\text { WBC }^{2}\end{array}$ & $\begin{array}{l}\text { Significant loss of } \\
\text { body weight }\end{array}$ & 1 of 8 animals diec \\
\hline \multicolumn{6}{|l|}{ AN-201 } \\
\hline Dose & $\begin{array}{l}150 \mathrm{nmol} / \mathrm{kg} \text { twice, } \\
\text { i.p. }\end{array}$ & $\begin{array}{l}110 \mathrm{nmol} / \mathrm{kg} \text { twice, } \\
\text { i.p. }\end{array}$ & $\begin{array}{l}250 \mathrm{nmol} / \mathrm{kg} \text { once, } \\
\text { i.v. }\end{array}$ & $\begin{array}{l}50 \mathrm{nmol} / \mathrm{kg} \text { twice, } \\
\text { i.p. }\end{array}$ & $\begin{array}{l}200 \mathrm{nmol} / \mathrm{kg} \text { once, } \\
\text { i.v. }\end{array}$ \\
\hline Effect & Not significant & $48 \%$ growth inhibition & $\begin{array}{l}1 \text { of } 10 \text { animals } \\
\text { cured }\end{array}$ & - & Not significant \\
\hline Toxicity & 9 of 10 animals died & 8 of 10 animals died & 1 of 10 animals died & All animals died & 3 of 8 animals diec \\
\hline
\end{tabular}

${ }^{1}$ Xenografted into nude mice; ${ }^{2}$ white blood cell.

Based on data from References 41, 58, 59, and 61.

the presence of receptors is crucial for the improved antitumor effect of the conjugate.

In another study aimed at the development of better methods for treatment of human epithelial ovarian cancers, we investigated the effect of cytotoxic analog of LHRH (AN-207), cytotoxic radical 2-pyrrolino-DOX (AN-201), the carrier [D-Lys ${ }^{6}$ ]LHRH, and the unconjugated mixture of AN-201 and the carrier on the growth of the LHRH receptor-positive OV-1063 human epithelial ovarian cancers (58) (Table 1). We determined that the growth of OV-1063 tumor was inhibited significantly by intraperitoneal administration of 150$250 \mathrm{nmol} / \mathrm{kg}$ doses of AN-207, but not by carrier [DLys $^{6}$ ]LHRH (58). Cytotoxic radical AN-201 and its mixture with carrier were toxic at these doses and killed all animals. Leukopenia, which is among the known side-effects of DOX and its derivatives, was also found to occur in animals treated with AN-207. Three days after administration of AN-207 at a dose of $5 \mathrm{nmol} / 20 \mathrm{~g}$, white blood cell (WBC) counts of nude mice decreased by $36.3 \%$, but after 7 days WBC values became normal. After treatment with AN-207, receptors for LHRH were not detectable, EGF receptor levels declined, and expression of mRNA for LHRH receptors and EGF receptors was decreased (58). We concluded that targeted cytotoxic LHRH analog AN-207 is less toxic than equimolar doses of its radical 2-pyrrolino-DOX and that it can effectively inhibit ovarian tumor growth. These two studies $(41,58)$ indicated that targeted chemotherapy based on analogs such as AN-152 and AN-207 may improve the management of ovarian cancer. Preliminary results also indicate that cytotoxic analog AN-207 inhibits growth of HEC-1A human endometrial cancers xenografted into nude mice.

\section{Breast cancer}

In an initial study on breast cancer, we tested tumor inhibitory action of targeted cytotoxic LHRH analogs $\mathrm{AN}-152$ and $\mathrm{AN}-207$ at various dose regimens in female BDF mice bearing estrogen-independent MXT mouse mammary cancers (59) (Table 1). The effects were compared with those obtained with the cytotoxic radicals DOX or AN-201 alone. Analog AN-207 and analog AN-152 given intraperitoneally as a single injection or repeatedly 2 days apart at their maximum tolerated doses resulted in a $89-93 \%$ inhibition of tumor growth (59). Equimolar amounts of the cytotoxic radicals were toxic. AN-207 administered twice at a dose between 100 and $175 \mathrm{nmol} / \mathrm{kg}$ had the strongest 
antitumor effect without significant toxicity. The optimal dose of AN-152, resulting in a 93\% inhibition of tumors without apparent toxicity, was about $35 \mu \mathrm{mol} / \mathrm{kg}$ (59). The advantage of AN-207 is that a dose about 150-200 times smaller than that of AN-152 can achieve the same effect.

The regimen of treatment for these new compounds is based on only one or two injections in contrast to continuous or daily administration used for the earlier cytotoxic LHRH analogs (57). At the doses and schedules of administration used in the present study, AN-207 and AN-152 had no significant long-lasting hormonal activity and serum LH, estradiol levels, and sex organ weights were not changed at the end of the experiments. Specific, high-affinity LHRH receptors were present on MXT tumor samples of control untreated mice, but no binding sites for LHRH could be found on tumor membranes after treatment with the cytotoxic LHRH analogs.

In another investigation, nude mice bearing MX-1 hormone-independent DOX-resistant human breast cancers were injected intravenously with $250 \mathrm{nmol} / \mathrm{kg}$ doses of AN-201, AN-207 (Table 1) or the unconjugated mixture of AN-201 and [D-Lys ${ }^{6}$ ]LHRH (60). Radioreceptor assays showed high-affinity binding sites for LHRH on MX-1 tumor cell membranes and the expression of mRNA for LHRH receptors was also found in tumors (60). Tumor growth and changes in hematological parameters were followed. AN-207 caused a complete regression of MX-1 tumors in all animals which remained tumor-free for at least 60 days after treatment (60). In contrast, therapy with AN-201 or the unconjugated mixture of AN-201 and [D-Lys $\left.{ }^{6}\right] \mathrm{LHRH}$ produced only transitory regression of MX-1 tumors. AN-201 caused animal deaths and significantly greater leukopenia than AN-207. These results suggest that targeted cytotoxic LHRH analogs such as AN-207 could be considered for treatment of advanced or metastatic breast cancers in women even for DOX-resistant tumors after the presence of receptors for LHRH is established (60).

\section{Prostate cancer}

Extensive investigations with new cytotoxic analogs of LHRH were also carried out in various models of prostate cancer. In the initial study, the effects of cytotoxic analog of LHRH, AN-207, were evaluated in rats bearing hormone-dependent Dunning R-3327-H prostate carcinomas (61) (Table 1). In the first experiment, we administered AN-207 intraperitoneally at a dose of $50 \mathrm{nmol} / \mathrm{kg}$. AN-201 was also given at the same dose as a single drug and as an unconjugated mixture with $\left[\mathrm{D}-\mathrm{Lys}^{6}{ }^{6}\right.$ LHRH. Following the second administration of $50 \mathrm{nmol} / \mathrm{kg} \mathrm{AN-201}$ alone or mixed with the carrier, all rats died with signs of general toxicity, but all animals treated with the conjugate AN-207 survived. After 5 weeks of treatment with a total dose of
$150 \mathrm{nmol} / \mathrm{kg} \mathrm{AN}-207$, the prostate tumors regressed to about one-half of their initial volume while tumors in the control group continued to grow (61). In another experiment, we compared the efficacy and toxicity of three intraperitoneal injections of $25 \mathrm{nmol} / \mathrm{kg}$ AN-201 or $25 \mathrm{nmol} / \mathrm{kg}$ and $50 \mathrm{nmol} / \mathrm{kg} \mathrm{AN-207}$. After 5 weeks of therapy, the tumors of rats treated with $50 \mathrm{nmol} / \mathrm{kg}$ AN-207 regressed. The reduction in tumor volume produced by $25 \mathrm{nmol} / \mathrm{kg} \mathrm{AN-201}$ and $25 \mathrm{nmol} / \mathrm{kg}$ AN-207 was similar, but AN-201 was still toxic in contrast to AN-207 (61). High-capacity LHRH receptors were found in the membranes of untreated Dunning tumors, but after treatment with AN-207 they could no longer be detected. This work showed that the cytotoxic analog AN-207 is much less toxic than its antineoplastic radical (AN-201) and significantly more active in inhibiting prostate tumor growth (61). This was the first demonstration that cytotoxic LHRH analog AN-207 can be an effective agent in treatment of prostate cancer (61).

In another study, we investigated the effect of cytotoxic analog AN-207 on the growth of LHRH receptor-positive $\mathrm{PC}-82$ human prostate cancer xenografted into nude mice (31) (Table 1). Analog AN-207, radical AN-201, carrier [D-Lys ${ }^{6}$ LHRH, or a mixture of [D-Lys ${ }^{6}$ ]LHRH and AN-201 were injected intravenously once at doses of $200 \mathrm{nmol} / \mathrm{kg}$. Tumor growth, body weight, total WBC counts and serum prostate-specific antigen (PSA) were determined (31). Eight weeks after administration of cytotoxic analog AN-207 there was a major reduction in tumor volume and tumor burden and a decrease in serum PSA levels as compared with controls. Only $12 \%$ of animals treated with AN-207 died. Cytotoxic radical AN-201 caused a minor and not significant reduction in tumor volume with no change in serum PSA and killed $40 \%$ of mice due to toxicity. Carrier [D-Lys ${ }^{6}$ LHRH and unconjugated mixture of [D-Lys ${ }^{6}$ ]LHRH and AN-201 caused no changes in tumor growth (31). Injection of AN-207 had no significant effect on the body weight but resulted in a fall in WBC and in platelet count after 1 week as compared with controls. This fall was smaller than that produced by AN-201 and the decrease in platelet count and WBC was no longer significant 2-3 weeks after treatment (31). A significantly stronger antiproliferative action and a much lower toxicity of AN-207, as compared with AN-201, in nude mice bearing xenografted PC-82 tumors could be attributed to a more selective delivery of analog AN-201 to PC-82 tumor cells (31). This view is supported by the presence of high-affinity binding sites for LHRH as well as the expression of mRNA for LHRH receptors in these tumors (31). Additional experimental studies and toxicological tests are required to further evaluate cytotoxic analogs of LHRH before they are used clinically, but targeted cytotoxic analogs of LHRH, such as AN-207, could eventually be used for the treatment of advanced prostate cancer after the relapse. Because of the presence of receptors for LHRH on a high percentage 
of prostate cancers, targeted chemotherapy based on cytotoxic analogs of these peptides should be more efficacious and less toxic than the currently used systemic chemotherapeutic regimens and might permit an escalation in doses. In addition, cytotoxic analogs of LHRH might also be indicated for primary therapy of patients with advanced prostate cancer, thus extending the oncological uses of LHRH analogs from the current palliation toward an eventual cure (23).

\section{Cytotoxic analogs of bombesin/ gastrin-releasing peptide (GRP)}

The bombesin-like peptides comprise a large family of peptides found in amphibians and man (62). After the tetradecapeptide bombesin was isolated from frog skin, two mammalian bombesin-like peptides were characterized, GRP which is a 27-amino acid peptide, and neuromedin $\mathrm{B}$ which is related to amphibian ranatensin (62). The carboxyl-terminal decapeptide of GRP is similar to that of bombesin and possesses all the biological activity of bombesin. The link between bombesin/GRP and small cell lung carcinoma (SCLC) was discovered by Cuttitta et al. (63) who found that SCLC cells both secrete and respond to bombesin-like peptides. Bombesin-like peptides are produced also in other cancers, such as breast, prostatic, and pancreatic cancer (23). The findings that bombesin/GRP function as autocrine growth factors for SCLC (63), and likely for other tumors (23), stimulated several laboratories, including ours, to synthesize receptor antagonists for hormonal treatment of these malignancies.

Four receptor subtypes associated with the bombesinlike peptides have been described and cloned $(62,64,65)$. These subtypes consist of the GRP-preferring subtype (62), the neuromedin B-preferring subtype (62), the bombesin receptor subtype 3 (BRS-3) present in lung cancer cell lines, the natural specific ligand of which is not yet known (64), and bombesin receptor subtype 4 (BRS-4 or BB4) that has a higher affinity for bombesin than for GRP (65). Specific receptors for bombesin/GRP have been demonstrated in human breast cancer and prostate cancer biopsies and in various human lung cancer, breast cancer, gastric and pancreatic cancer cell lines $(23,66,67)$.

Bombesin/GRP antagonist such as RC-3095 (D-Tpi ${ }^{6}$,$\mathrm{Leu}^{13} \Psi\left(\mathrm{CH}_{2} \mathrm{NH}\right)$-Leu ${ }^{14}$-bombesin $\left.(6-14)\right)$ and related analogs block the binding of bombesin to the receptors on Swiss 3T3 cells and various human cancers (23, 68, 69). These nonapeptide antagonists inhibit the growth of MXT breast cancers in mice, nitrosamineinduced pancreatic cancers in hamsters, and various human cancer lines such as HT-29 colon cancer, PC82, PC-3 and DU-145 prostate cancers, MKN-45 gastric carcinoma, CFPAC-1 and SW-1990 pancreatic cancer, H-69 SCLC, and MDA-MB-231 and MCF-7 MIII breast cancers xenografted into nude mice (23, 67, 68). More powerful antagonists, such as
$\mathrm{Hca}^{6}{ }^{6} \mathrm{Leu}^{13}, \Psi\left(\mathrm{CH}_{2} \mathrm{~N}\right) \mathrm{Tac}^{14}$-BN(6-14) (RC-3940-II) show a higher binding affinity to the receptors on tumor cells and greater antitumor activity than RC-3095 (70). Ongoing clinical studies should determine the possible application of bombesin/GRP antagonists in treatment of various cancers $(23,68)$.

The presence of receptors for bombesin-like peptides on a wide variety of tumors prompted us to use some of our powerful bombesin/GRP antagonists as carrier molecules for targeting cytotoxic agents to tumor cells (71). We assumed that such cytotoxic bombesin analogs would be more potent than the straight bombesin/GRP antagonists and that they could produce a complete tumor regression and not merely a palliative stabilization.

The chemistry developed for the preparation of highly active cytotoxic LHRH hybrids containing DOX or AN201 was used for the synthesis of cytotoxic bombesinlike analogs (71). To produce conjugates with high binding affinity to receptors for bombesin/GRP on various tumors, we selected as carriers our bombesin antagonists containing the amino acid sequence 6-14 of bombesin and a reduced peptide bond between residues 13 and $14(69,70)$. The cytotoxic radicals were linked to the amino terminal of these peptides (71). The resulting conjugates showed binding affinities to bombesin/GRP receptors on Swiss 3T3 cells comparable with that of their respective carriers (71). Conjugates consisting of the cytotoxic radical and bombesin 7-14 carriers such as AN-215 (Des-D-Tpi RC-3095 linked to 2-pyrrolino-DOX-14-O-hemiglutarate), that is octapeptide analogs 1 amino acid shorter than the RC class of antagonists, showed the highest binding affinity to receptors for bombesin/GRP $\left(K_{\mathrm{D}} \approx 1 \mathrm{nmol} / \mathrm{l}\right)(71)$. The cytotoxic bombesin analogs and their corresponding cytotoxic radicals exerted similar inhibitory effects on the in vitro growth of CFPAC-1 human pancreatic cancer, DMS-53 human lung cancer, PC-3 human prostate cancer, and MKN-45 human gastric cancer cell lines that have receptors for bombesin/GRP. In DMS-53 cells, the activity of 2-pyrrolino-DOX and its conjugates was $\approx 2500$ times higher than that of DOX and its hybrids (71).

Preliminary in vivo experiments on nitrosamineinduced pancreatic cancers in golden hamsters indicated that cytotoxic bombesin analog AN-215 had significant antitumor activity and lower toxicity than the unconjugated cytotoxic radical.

We then evaluated whether bombesin receptors could be used for targeting cytotoxic bombesin analogs to $\mathrm{H}-$ 69 SCLC in vivo (72). Male nude mice bearing xenografted H-69 SCLC cell line received an intravenous injection of AN-215 or AN-201 (72). The growth of SCLC H-69 tumors was significantly inhibited by the treatment with $200 \mathrm{nmol} / \mathrm{kg} \mathrm{AN-215}$ as compared with the control groups, while equimolar doses of the cytotoxic radical AN-201 were toxic and produced only a minor tumor inhibition. mRNA for bombesin 
receptors was detected in H-69 tumors and bombesin/ GRP binding sites were shown on $\mathrm{H}-69$ tumor membranes (72). This supports the concept that cytotoxic bombesin analog $\mathrm{AN}-215$ was preferentially targeted to H-69 SCLC tumors. Collectively, these results demonstrate that the cytotoxic bombesin analog AN-215 could be used for targeted therapy of tumors that express bombesin receptors such as SCLC (71). In addition to SCLC, cytotoxic bombesin analogs might also find application in the treatment of colorectal, gastric, pancreatic, mammary, prostatic, brain tumors, and other cancers (71).

\section{Cytotoxic analogs of somatostatin}

Tetradecapeptide somatostatin has many biological actions and appears to be an endogenous antiproliferative agent $(23,73,74)$. The oncological potential of somatostatin has been appreciated for more than 20 years, but its half-life is very short, so that its therapeutic use is impractical (23). Several groups synthesized somatostatin analogs with more selective and prolonged activities (23, 74-77). Among these analogs, D-Phe-Cys-Phe-D-Trp-Lys-Thr-Cys-Thr-OL (SMS201-995, Sandostatin, octreotide) (75) and D-Phe-CysTyr-D-Trp-Lys-Val-Cys-Trp- $\mathrm{NH}_{2}$ (RC-160, Vapreotide, Octastatin) (76) and BIM-23014 (Somatulin; D-Nal(2)-

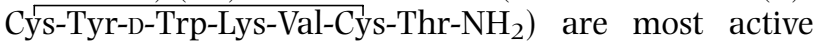
(77). RC-160 is much more potent than Sandostatin or BIM-23014 in oncological tests in vitro due to its higher affinity for somatostatin receptors (78). Most studies on potential clinical applications in oncology were carried out with these three analogs. Attempts are being made to use modern somatostatin analogs for the therapy of human breast cancer, prostate cancer, carcinoma of exocrine pancreas, colorectal cancer, gastric cancer as well as brain tumors and lung cancers (reviewed in references 23, 73, 74, 77).

Antitumoral action of somatostatin analogs could be direct or indirect $(74,77)$. The indirect mechanism would operate through a suppression of the growth hormone $(\mathrm{GH})$ release from the pituitary and the resulting inhibition of the hepatic production of insulin-like growth factor-I (IGF-I) $(74,77)$. The fall in IGF-I could inhibit growth of various tumors since IGF-I and -II and other growth factors, including EGF, appear to be involved in the proliferation of neoplastic cells (74, 77). An antineoplastic action of a somatostatin analog is defined as 'direct' if it is a consequence of binding of the analog to somatostatin receptors present on tumor cells (77). High- or low-affinity somatostatin-14 receptors were identified in various normal tissues and human neoplasms, including brain tumors, pituitary tumors, gastrointestinal tumors, breast cancers, SCLC and non-SCLC cell lines, pancreatic cancers, colorectal cancer, human prostate cancers, and in human ovarian cancers $(23,77,79-83)$. More recently, somatostatin binding sites have been classified with respect to receptor subtype. Five subtypes of somatostatin receptor, SSTR-1 to SSTR-5, have been cloned and functionally characterized (84-88). They all bind somatostatin-14 and somatostatin-28 with similar affinity but show major differences in their affinities for various somatostatin analogs (77). Sandostatin (Octreotide) and RC-160 have a low affinity for SSTR-1, but both possess a high binding affinity for receptor subtype SSTR-2 (89). RC-160 also exhibited moderate to high affinities for SSTR-3 and -5 and low affinity for SSTR-4 (90). Since mRNAs of receptor subtypes are variably expressed in different cancers, a precise determination of receptor subtypes in tumor tissue is necessary before therapy with analogs $(89,90)$. Thus, a recent report by Buscail et al. (91) indicates that most human pancreatic and colorectal cancers do not express SSTR-2, but SSTR-5 is still expressed.

Radioiodinated analogs of somatostatin such as $\left[{ }^{111}\right.$ In-DTPA-D-Phe ${ }^{1}$-octreotide (Octreoscan) have been used clinically for the localization of tumors containing receptors for somatostatin (92). Various primary tumors, both neuroendocrine or non-neuroendocrine, containing high numbers of somatostatin receptors, and metastases can be visualized by scintigraphy (92). Work is also in progress on application of somatostatin analogs labeled with appropriate radionuclides such as ${ }^{186}$ Rhenium or ${ }^{90}$ Yttrium in cancer therapy (93). A better approach might consist of targeting chemotherapeutic agents linked to somatostatin analogs to receptors for somatostatin in certain cancers (23).

In an initial study, an early cytotoxic analog AN-51 consisting of methotrexate linked to the N-terminal of somatostatin octapeptide analog D-Phe-Cys-Tyr-D-TrpLys-Val-Cys-Thr-NH $\mathrm{NH}_{2}$ (RC-121) was tested in nude mice bearing transplanted MIA PaCa-2 human pancreatic cancers (22). The treatment with AN-51 inhibited tumor growth, whereas methotrexate or RC-121 administered singly had no significant effect (22). AN-51 also showed high specific binding affinity to receptors for somatostatin on rat cortex, Dunning R 3327 rat prostate cancers and MIA-PaCa-2 human pancreatic cancers (22). These findings indicated a bulk tolerance of the carrier for modification at the amino terminal. Thus, to create cytotoxic somatostatin hybrids containing DOX or AN-201, we used octapeptide analogs RC-160 and RC-121 developed in our institute (76). N-Fmoc-DOX14-O-hemiglutarate was linked to the amino terminal of $\left[\mathrm{Lys}(\mathrm{Fmoc})^{5}\right] \mathrm{RC}-121$ to form, after removal of the Fmoc protection, the cytotoxic somatostatin analog AN-162 containing DOX (94). In contrast to cytotoxic analogs of LHRH or bombesin containing DOX, AN-162 could not be converted to 2-pyrrolino-DOX analog by a reaction with 4-iodobutyraldehyde because of side reactions (94). To prepare cytotoxic somatostatin analogs containing AN-201, DOX-14-O-hemiglutarate was synthesized and reacted with 4-iodobutyraldehyde to yield 2-pyrrolino-DOX-14-O-hemiglutarate. This moiety was in turn coupled to the amino terminal of $\left[\mathrm{Lys}(\mathrm{Fmoc})^{5}\right] \mathrm{RC}-121$. After removal of the Fmoc 


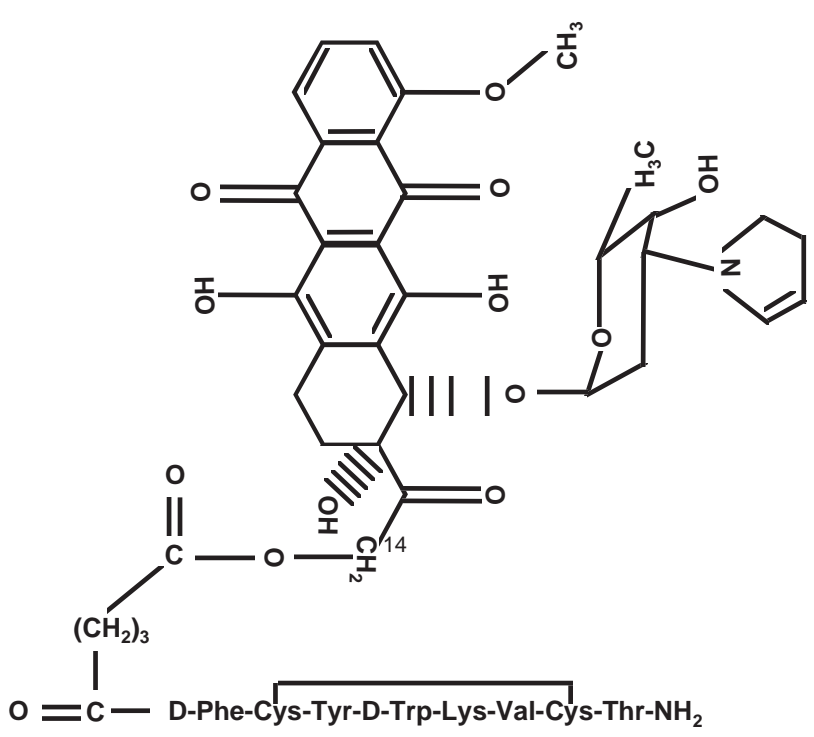

Figure 3 Molecular structure of cytotoxic somatostatin analog AN238. Somatostatin analog RC-121 is linked through the $\alpha$-amino group of its D-Phe moiety and a glutaric acid spacer to the $14-\mathrm{OH}$ group of 2-pyrrolino-DOX (AN-201) (94). Copyright (1998) National Academy of Sciences, USA. This figure is reprinted with permission from Proceedings of the National Academy of Sciences of the USA.

protecting group, AN-238 (Fig. 3) was obtained in a moderate yield (94). AN-238 was shown to bind with high affinity to SSTRs on membrane preparations of rat pituitary and Dunning AT-1 rat prostatic tumors. In vitro tests on human cancer cell lines, including MKN-45 gastric cancer, MDA-MB-231 breast cancer, PC-3 prostate cancer, and MIA $\mathrm{PaCa}-2$ pancreatic cancer, demonstrated that the antiproliferative activity of the cytotoxic radicals in these analogs was retained (94). In H-345 human SCLC cell line, conjugates of RC-121 similarly preserved the cytotoxic activity of their radicals. $\mathrm{AN}-238$ also inhibited the GH-releasing hormone- or forskolin-induced $\mathrm{GH}$ release from superfused rat pituitary cells at similar nanomolar concentrations as the carrier RC-121 (94).

Oncological studies on AN-238 were carried out in animal models of breast and prostate cancers to determine its toxicity and potency in inhibiting tumor growth (Table 2). Thus, the effects of targeted cytotoxic somatostatin analog (AN-238) on tumor growth and hematologic parameters were studied in three human breast cancer models (95). The models included estrogen-independent MDA-MB-231 and MX-1 cancers and the estrogen-sensitive MCF-7-MIII tumors. Highaffinity receptors for somatostatin and mRNA for both SSTR-2 and SSTR-5 were found in all three types of tumors (95) in accord with an earlier study by Evans et al. (96) of gene expression on SSTR subtypes in human breast cancers. Nude mice bearing xenografts of these cancers were injected intravenously with
$250 \mathrm{nmol} / \mathrm{kg}$ doses of cytotoxic radical AN-201, cytotoxic somatostatin analog $\mathrm{AN}-238$, or the unconjugated mixture of $\mathrm{AN}-201$ and carrier RC-121. A significant inhibition of growth of MDA-MB-231, MX-1 and MCF-7-MIII tumors was observed 1 week after injection of a single dose of cytotoxic analog AN-238 (Table 2). The volumes and weights of MCF-7-MIII tumors and MDA-MB-231 tumors were still reduced 60 days after treatment with AN-238. AN-238 also caused a complete regression of MX-1 tumors in $50 \%$ of animals which remained tumor-free 60 days after treatment (95). In contrast, MDA-MB-231 and MCF-7-MIII tumors continued to grow after treatment with cytotoxic radical AN-201 and MX-1 tumors regressed only temporarily. The toxicity of AN-201 was much greater than that of $\mathrm{AN}-238$ as measured by animal deaths, loss of body weight, and leukopenia. These results demonstrated that cytotoxic somatostatin analog AN-238 efficaciously inhibits growth of human breast cancers expressing SSTRs- 2 and -5 and can be used for receptor-targeted chemotherapy (95).

We also evaluated the effects of AN-238 on the growth of androgen-independent Dunning R-3327-AT-1 prostate cancers in Copenhagen rats (97) (Table 2). Specific high-affinity receptors for somatostatin were found on Dunning R-3327-AT-1 tumor membranes by radioligand binding assay and were identified by RT-PCR as SSTR subtype 2 (97). Administration of cytotoxic radical AN-201 at single intravenous doses of 115$150 \mathrm{nmol} / \mathrm{kg}$ caused severe thrombocytopenia and loss of body weight and resulted in a 90-100\% mortality. In contrast, a single intravenous injection of analog $\mathrm{AN}-238$ at a dose of $300 \mathrm{nmol} / \mathrm{kg}$ was non-toxic and remarkably potent in inhibiting the growth of Dunning AT- 1 tumors resulting in an $85.9 \%$ reduction in tumor volume 4 weeks after injection. Even a low dose of $115 \mathrm{nmol} / \mathrm{kg} \mathrm{AN}-238$ caused a $40 \%$ reduction in tumor volume (97). Treatment with AN-238 prolonged the survival time of tumor-bearing rats by $76.5 \%$. No reduction in tumor growth was observed with carrier RC-121, but after the injection of unconjugated mixture of $\mathrm{AN}-201$ and $\mathrm{RC}-121$ at doses of $300 \mathrm{nmol} / \mathrm{kg}$, all rats died in 4 days. Our study indicates that cytotoxic somatostatin analog $\mathrm{AN}-238$ can be targeted to somatostatin receptors on tumors and produces a powerful inhibition of the growth of Dunning AT-1 prostate cancer at doses which are non-toxic, while its cytotoxic component, 2-pyrrolino-DOX, is toxic and ineffective (97). Our findings suggest that targeted cytotoxic somatostatin analogs could be more efficacious and less toxic than presently used systemic chemotherapeutic agents for the therapy of patients with advanced metastatic prostate cancer who no longer respond to androgen deprivation (97).

In a recent study, we evaluated whether AN-238 could be used for targeting human primary and metastatic prostate carcinomas that express SSTR-2 and SSTR-5 (98). The antitumor activity of AN-238 was 


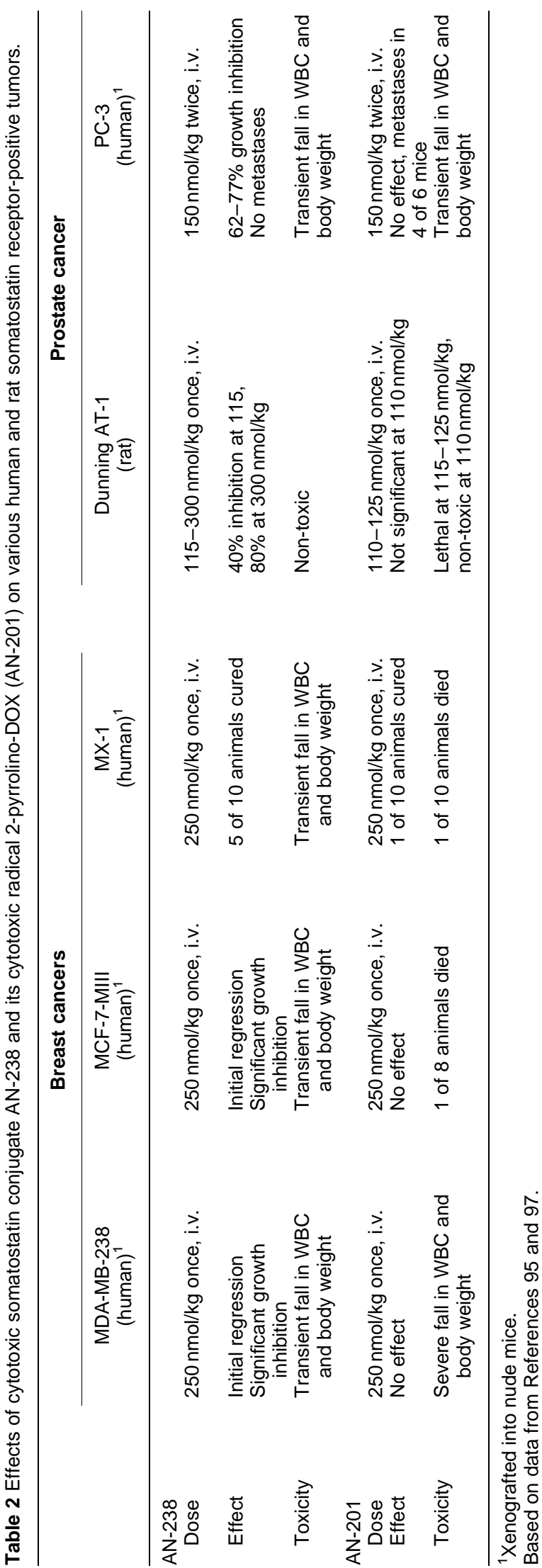

first investigated in nude mice bearing subcutaneous xenografts of PC-3 human androgen-independent prostatic cancer. AN-238 injected once i.v. at $200 \mathrm{nmol} / \mathrm{kg}$ induced a $74 \%$ decrease in tumor volume and a $71 \%$ reduction in tumor weight after 7 weeks. AN-201 at an equimolar dose did not show any antitumor activity (98). Two i.v. injections of AN-238 at $150 \mathrm{nmol} / \mathrm{kg}, 10$ days apart, inhibited tumor volume by $62.3 \%$ and tumor weight by $61.1 \%$ after 4 weeks of treatment. The suppression of tumor growth induced by AN-238 was accompanied by a significant enhancement of apoptosis (98). The effectiveness of AN-238 in a metastatic model was then investigated in animals implanted orthotopically with PC-3 cells. Two i.v. injections of AN-238 at $150 \mathrm{nmol} / \mathrm{kg}, 10$ days apart, reduced the weight of primary tumors by $77 \%(P<0.01)$ after 4 weeks of treatment (98). All control animals developed metastases into lymph nodes; however, no lymphatic spread of cancer was found in the AN-238-treated group. RT-PCR analysis demonstrated an expression of SSTR-2 and SSTR-5 in intraprostatic tumors, their metastases into lymph nodes, as well as in subcutaneous tumors (98). This study demonstrated a high efficacy of SSTR-targeted chemotherapy in a model of disseminated human androgen-independent prostatic carcinoma (98). The use of cytotoxic somatostatin analog AN-238 could provide an effective therapy for patients with advanced prostatic carcinoma who relapsed androgen ablation.

Other studies in progress show that growth of various human pancreatic, colorectal and gastric cancers in nude mice as well as glioblastomas and non-SCLC can be suppressed by cytotoxic somatostatin analogs. Thus cytotoxic somatostatin analogs might find applications for the therapy of human breast cancer, prostate cancer, pancreatic, colorectal and gastric cancer as well as brain tumors and non-SCLC.

\section{Discussion}

It should be emphasized that cytotoxic peptide conjugates like AN-238 or AN-207 containing AN-201 are very active intravenously in $200 \mathrm{nmol} / \mathrm{kg}$ doses corresponding to $0.4-0.45 \mathrm{mg} / \mathrm{kg}$ or $8-9 \mu \mathrm{g} / 20 \mathrm{~g}$ mouse. The estimated human doses would be about $22.5 \mathrm{mg} / 50 \mathrm{~kg}$.

The mechanism of action of these cytotoxic analogs is the subject of intense investigations in several laboratories. It is assumed that a peptide containing a cytotoxic radical may be bound to the membrane receptors and internalized. Thus, a cytotoxic LHRH analog T-98 containing an anthraquinone derivative coupled to [D-Lys $\left.{ }^{6}\right] \mathrm{LHRH}$ is internalized by rat pituitary cells (99). A similar internalization could occur in cancer cells which contain receptors for LHRH. After endocytosis, such a compound could interfere with intracellular events in cancer cells. Analogs containing DOX may also kill cancer cells by membrane action on the cell surface without entering the cell $(18,100,101)$. 
The damage inflicted by cytotoxic analogs to pituitary cells secreting $\mathrm{LH}$, follicle-stimulating hormone, and $\mathrm{GH}$ would not be deleterious to the cancer patient since hypophysectomy has been used for treatment of some cancers (23). These studies indicate that cytotoxic LHRH analogs such as AN-207 have a selective and transient effect on LH cells but not on GH and prolactin cells while cytotoxic radical AN-201 non-selectively damages the pituitary cells (102). A possible damage to other cells, e.g. corticotrophs, thyrotrophs, could also be alleviated by replacement therapy.

\section{Conclusions}

Cytotoxic compounds linked to analogs of hormonal peptides like LHRH, bombesin, and somatostatin can be targeted to certain tumors possessing receptors for those peptides and therefore are more selective for killing cancer cells. Cytotoxic peptide analogs are much less toxic than the respective chemotherapeutic agents and thus could be an important addition to oncological armamentarium. The results of experimental studies in ovarian, mammary, and prostate cancer models reviewed herein demonstrate the capability of cytotoxic analogs of LHRH and somatostatin to inhibit growth and even cause regression of various tumors. Our work supports the view that the use of targeted chemotherapy may permit an escalation of doses and improve the treatment outcome. It is also possible that repeated administration of cytotoxic analogs may totally eradicate some cancers. The approach based on cytotoxic analogs of LHRH, bombesin, and somatostatin requires additional experimental work and remains to be tested clinically. Nevertheless, our work indicates that the advances in cytotoxic peptide analogs are likely to result in major improvements in clinical management of various cancers.

\section{Acknowledgements}

Some experimental work described in this paper was supported by the Medical Research Service of the Veterans Affairs Department, an award from CaP CURE (Association for the Cure of Prostate Cancer) and a grant from ASTA Medica to Tulane University School of Medicine (to AVS). We are grateful to Professor Jürgen Engel, Professor B Kutscher, Dr M Bernd, and Dr T Nolte, ASTA Medica, Frankfurt/M, for valuable advice and extensive help in this project, and to Dr E Busker, Degussa, Hanau-Wolfgang, Germany, for mass spectra and NMR analyses. We thank our colleagues Dr M Koppán, Dr R-Z Cai, Dr K Szepeshazi, Dr Z Kahán, Dr H Kiaris, Dr A Plonowski, Dr V Csernus, Dr M Miyazaki, Dr M Kovács, Dr J Arencibia, Dr Kate Groot and P Armatis for important contributions on new cytotoxic analogs cited in this review.

\section{References}

1 Chabner B. Cancer Chemotherapy. Principles and Practice. Philadelphia: J B Lippincott, 1990.

2 Frei E III \& Antman KH. Combination chemotherapy, dose, and schedule. In Cancer Medicine, edn 4, pp 817-837. Eds JR Holland, E Frei III, RR Bast Jr, DE Kufe, DL Morton \& RR Weichselbaum. Baltimore: Williams and Wilkins, 1997.

3 Magrath T. Targeted approaches to cancer therapy. International Journal of Cancer 199456 163-166.

4 Ehrlich P. The relationship existing between chemical constitution, distribution, and pharmacological action. In The Collected Papers of Paul Ehrlich, vol. 1, pp 596-618. Eds F Himmelweite, M Marquardt \& H Dale. Elmsford, New York: Pergamon, 1956.

5 Kohler G \& Milstein C. Continuous cultures of fused cells secreting antibody of predefined specificity. Nature 1975256 495-497.

6 Baldwin RW. Monoclonal antibody targeting of anticancer agents: Mühlbock Memorial Lecture. European Journal of Cancer and Clinical Oncology 198521 1281-1285.

7 Hertler AA \& Frankel AE. Immunotoxins: A clinical review of their use in the treatment of malignancies. Journal of Clinical Oncology 19897 1932-1942.

8 Pastan I \& FitzGerald D. Recombinant toxins for cancer treatment. Science $19912541173-1177$.

9 FitzGerald D \& Pastan I. Targeted toxin therapy for the treatment of cancer. Journal of the National Cancer Institute 198981 14551463.

10 Singh V, Sairam MR, Bhargavi GN \& Akhras RG. Hormonotoxins. Preparation and characterization of ovine luteinizing hormonegelonin conjugate. Journal of Biological Chemistry 1989264 3089-3095.

11 Yeh M-Y, Roffler SR \& Yu M-H. Doxorubicin: Monoclonal antibody conjugate for therapy of human cervical carcinoma. International Journal of Cancer $199251274-282$.

12 Schally AV, Nagy A, Szepeshazi K, Pinski J. Halmos G, Armatis P et al. LH-RH analogs with cytotoxic radicals. In Treatment with Gn-RH Analogs: Controversies and Perspectives, pp 33-44. Eds M Filicori \& C Flamigni. Carnforth, UK: Parthenon Publishing, 1996.

13 Konyves I. Estramustine phosphate (Estracyt) in the treatment of prostate carcinoma. International Urology and Nephrology 1989 21 393-397.

14 Konyves I, Muntzing J \& Rozencweig M. Chemotherapy principles in the treatment of prostatic cancer. Prostate 19845 $55-62$.

15 Freer RJ \& Stewart JM. Alkylating analogs of peptide hormones. 1. Synthesis and properties of $p$-[N,N-Bis(2-chloroethyl)amino]phenylbutyryl derivatives of bradykinin and bradykinin potentiating factor. Journal of Medicinal Chemistry 1972 15 1-5.

16 Channabasavaiah K \& Stewart JM. New analogs of luliberin which inhibit ovulation in the rat. Biochemical and Biophysical Research Communications 197986 1266-1273.

17 Paiva TB, Paiva ACM, Freer RJ \& Stewart JM. Alkylating analogs of peptide hormones. 2. Synthesis and properties of $p$-[N,N-Bis $(2-$ chloroethyl)amino]phenylbutyryl derivatives of angiotensin II. Journal of Medicinal Chemistry 197215 6-8.

18 Varga JM. Hormone-drug conjugates. Methods in Enzymology $1985112259-269$.

19 Bajusz S, Janáky T, Csernus VJ, Bokser L, Fekete M, Srkalovic G et al. Highly potent analogues of luteinizing hormone-releasing hormone containing D-phenylalanine nitrogen mustard in position 6. Proceedings of the National Academy of Sciences of the USA $1989866318-6322$.

20 Bajusz S, Janáky T, Csernus VJ, Bokser L, Fekete M, Srkalovic G et al. Highly potent metallopeptide analogues of luteinizing hormone-releasing hormone. Proceedings of the National Academy of Sciences of the USA 198986 6313-6317.

21 Janáky T, Juhász A, Bajusz S, Csernus V, Srkalovic G, Bokser L et al. Analogues of luteinizing hormone-releasing hormone containing cytotoxic groups. Proceedings of the National Academy of Sciences of the USA 199289 972-976. 
22 Radulovic S, Nagy A, Szöke B \& Schally AV. Cytotoxic analog of somatostatin containing methotrexate inhibits growth of MIA PaCa-2 human pancreatic cancer xenografts in nude mice. Cancer Letters 199262 263-271.

23 Schally AV \& Comaru-Schally AM. Hypothalamic and other peptide hormones. In Cancer Medicine, edn 4, pp 1067-1086. Eds JR Holland, E Frei III, RR Bast Jr, DE Kufe, DL Morton \& RR Weichselbaum. Baltimore: Williams and Wilkins, 1997.

24 Emons G \& Schally AV. The use of luteinizing hormone-releasing hormone agonists and antagonists in gynecological cancer. Human Reproduction 19949 1364-1369.

25 Schally AV, Comaru-Schally AM, Gonzalez-Barcena D, Reissmann $\mathrm{T} \&$ Engel J. Antagonistic analogs of LH-RH in oncology and gynecology. In Endometriosis Today: Advances in Research and Practice. Proceedings of the $\mathrm{V}^{\text {th }}$ World Congress of Endometriosis, October 1996, Yokohama, Japan, pp 401-413. Eds H Minaguchi \& O Sugimioto. Carnforth, UK: Parthenon Publishing, 1997.

26 Schally AV \& Comaru-Schally AM. Rational use of agonists and antagonists of luteinizing hormone-releasing hormone (LH-RH) in the treatment of hormone-sensitive neoplasms and gynaecologic conditions. Advanced Drug Delivery Reviews 199728 157169.

27 Emons G, Ortmann O, Schulz K-D \& Schally AV. Growthinhibitory actions of analogues of luteinizing hormone-releasing hormone on tumor cells. Trends in Endocrinology and Metabolism $19978355-362$.

28 Stojilkovic SS \& Catt KJ. Expression and signal transduction pathways of gonadotropin releasing hormone receptors. Recent Progress in Hormone Research 199530 161-205.

29 Fekete M, Redding TW, Comaru-Schally AM, Pontes AE, Connelly RW, Srkalovic G et al. Receptors for luteinizing hormonereleasing hormone, somatostatin, prolactin and epidermal growth factor in rat and human prostate cancers and in benign prostatic hyperplasia. Prostate 198914 191-208.

30 Oayum A, Gullick W, Clayton RC, Sikora K \& Waxman J. The effects of gonadotrophin releasing hormone analogues in prostate cancer are mediated through specific tumor receptors. British Journal of Cancer 199062 96-99.

31 Koppán M, Nagy A, Schally AV, Plonowski A, Halmos G, Arencibia JM et al. Targeted cytotoxic analog of luteinizing hormone-releasing hormone AN-207 inhibits the growth of PC82 human prostate cancer in nude mice. Prostate 199938151 158 .

32 Limonta P, Dondi D, Moretti RM, Maggi R \& Motta M. Antiproliferative effects of luteinizing hormone-releasing hormone agonists on the human prostatic cancer cell line LNCaP. Journal of Clinical Endocrinology and Metabolism 199275 207212 .

33 Lamharzi N, Halmos G, Jungwirth A \& Schally AV. Decrease in the level and mRNA expression of LH-RH and EGF receptors after treatment with LH-RH antagonist Cetrorelix in DU-145 prostate tumor xenografts in nude mice. International Journal of Oncology $199813429-435$.

34 Limonta P, Dondi D, Moretti RM, Fermo D, Garattini E \& Motta M Expression of luteinizing hormone-releasing hormone mRNA in the human prostatic cancer cell line LNCaP. Journal of Clinical Endocrinology and Metabolism 199376 797-800.

35 Miller WR, Scott WN, Morris R, Fraser HM \& Sharpe RM. Growth of human breast cancer cells inhibited by a luteinizing hormonereleasing hormone agonist. Nature 1985313 231-233.

36 Eidne KA, Flanagan CA, Harris NS \& Millar RP. Gonadotropinreleasing hormone (GnRH)-binding sites in human breast cancer cell lines and inhibitory effects of GnRH antagonists. Journal of Clinical Endocrinology and Metabolism 198764 425-432.

37 Yano T, Korkut E, Pinski J, Szepeshazi K, Milovanovic S, Groot K et al. Inhibition of growth of MCF-7-MIII human breast carcinoma in nude mice by treatment with agonists or antagonists of LH-RH Breast Cancer Research and Treatment 199221 35-45.

38 Fekete M, Wittliff JL \& Schally AV. Characteristics and distribution of receptors for [D-Trp ${ }^{6}$ ]-luteinizing hormone-releasing hormone, somatostatin, epidermal growth factor, and sex steroids in 500 biopsy samples of human breast cancer. Journal of Clinical Laboratory Analysis 19893 137-147.

39 Srkalovic G, Schally AV, Wittliff JL, Day TG \& Jenison EL. Presence and characteristics of receptors for [D-Trp ${ }^{6}$ ] luteinizing hormonereleasing hormone and epidermal growth factor in human ovarian cancer. International Journal of Oncology 199812 489498.

40 Irmer G, Bürger C, Müller R, Ortman O, Peter V, Kakar S et al. Expression of the messenger RNAs for luteinizing hormonereleasing hormone (LHRH) and its receptor in human ovarian epithelial carcinoma. Cancer Research 199555 817-822.

41 Miyazaki M, Nagy A, Schally AV, Lamharzi N, Halmos G, Szepeshazi K et al. Growth inhibition of human ovarian cancers by cytotoxic analogues of luteinizing hormone-releasing hormone. Journal of the National Cancer Institute 199789 1803-1809.

42 Srkalovic G, Wittliff JL \& Schally AV. Detection and partial characterization of receptors for [D-Trp $\left.{ }^{6}\right]$-luteinizing hormonereleasing hormone and epidermal growth factor in human endometrial carcinoma. Cancer Research $1990 \quad 50$ 18411846 .

43 Emons G, Schröder B, Ortmann O, Westphalen S, Schulz K-D \& Schally AV. High affinity binding and direct antiproliferative effects of luteinizing hormone-releasing hormone analogs in human endometrial cancer cell lines. Journal of Clinical Endocrinology and Metabolism 199377 1458-1464.

44 Kakar SS, Grizzle WE \& Neill JD. The nucleotide sequences of human GnRH receptors in breast and ovarian tumors are identical with that found in pituitary. Molecular and Cellular Endocrinology 1994106 145-149.

45 Halmos G, Nagy A, Lamharzi N \& Schally AV. Cytotoxic analogs of luteinizing hormone-releasing hormone bind with highaffinity to human breast cancers. Cancer Letters 1999136 129-136.

46 Karten MJ \& Rivier JE. Gonadotropin-releasing hormone analog design. Structure-function studies toward the development of agonists and antagonists: rationale and perspective. Endocrine Reviews $1986744-66$.

47 Nagy A, Szöke B \& Schally AV. Selective coupling of methotrexate to peptide hormone carriers through a $\gamma$-carboxamide linkage of its glutamic acid moiety: Benzotriazol-1-yloxytris(dimethylamino)phosphonium hexafluorophosphate activation in salt coupling. Proceedings of the National Academy of Sciences of the USA $1993906373-6376$.

48 Hurwitz E, Levy R, Maron R, Wilchek M, Arnon R \& Sela M. The covalent binding of daunomycin and adriamycin to antibodies, with retention of both drug and antibody activities. Cancer Research 197535 1175-1181.

49 Casazza AM, Trail PA \& Hellstrom KE. Drug immunotargeting for carcinomas: a reality at last? Annals of Oncology 19945 703708.

50 Shen WC \& Ryser HJP. cis-Aconityl spacer between daunomycin and macromolecular carriers: A model of $\mathrm{pH}$-sensitive linkage releasing drug from lysosomotropic conjugate. Biochemical and Biophysical Research Communications 1981102 1048-1054.

51 Trouet A, Masquelier M, Baurain R \& Deprez-de Campeneere D. A covalent linkage between daunorubicin and proteins that is stable in serum and reversible by lysosomal hydrolases, as required for a lysosomotropic drug-carrier conjugate: in vitro and in vivo studies. Proceedings of the National Academy of Sciences of the USA $198279626-629$.

52 Zunino F, Gambetta R, Vigevani A, Penco S, Geroni C \& DiMarco A. Biological activity of daunorubicin linked to proteins via the methylketone side chain. Tumori 198167 521-524.

53 Zunino F, Savi G, Giuliani F, Gambetta R, Supino R, Tinelli S et al. Comparison of antitumor effects of daunorubicin covalently linked to poly-L-amino acid carriers. European Journal of Cancer and Clinical Oncology 198420 421-425.

54 Nagy A, Schally AV, Armatis P, Szepeshazi K, Halmos G, Kovacs $\mathrm{M}$ et al. Cytotoxic analogs of luteinizing hormone-releasing 
hormone containing doxorubicin or 2-pyrrolinodoxorubicin, a derivative 500-1000 times more potent. Proceedings of the National Academy of Sciences of the USA 199693 7269-7273.

55 Nagy A, Armatis P \& Schally AV. High-yield conversion of doxorubicin to 2-pyrrolinodoxorubicin, an analog 500-1000 times more potent: Structure-activity relationship of daunosamine-modified derivatives of doxorubicin. Proceedings of the National Academy of Sciences of the USA 199693 2464-2469.

56 Pinski J, Schally AV, Yano T, Szepeshazi K, Halmos G, Groot K et al. Inhibition of growth of experimental prostate cancer in rats by LH-RH analogs linked to cytotoxic radicals. Prostate 199323 165-178.

57 Szepeshazi K, Schally AV, Juhász A, Nagy A \& Janáky T. Effects of luteinizing hormone-releasing hormone analogs containing cytotoxic radicals on growth of estrogen-independent MXT mouse mammary carcinoma in vivo. Anti-Cancer Drugs 19923 109-116.

58 Miyazaki M, Schally AV, Nagy A, Lamharzi N, Halmos G, Szepeshazi K et al. Targeted cytotoxic analog of luteinizing hormone-releasing hormone AN-207 inhibits growth of OV1063 human epithelial ovarian cancers in nude mice. American Journal of Obstetrics and Gynecology 1999 (In Press).

59 Szepeshazi K, Schally AV, Nagy A, Halmos G \& Groot K. Targeted cytotoxic luteinizing hormone releasing hormone (LH-RH) analogs inhibit growth of estrogen-independent MXT mouse mammary cancers in vivo by decreasing cell proliferation and inducing apoptosis. Anti-Cancer Drugs 19978 974-987.

60 Kahán Z, Nagy A, Schally AV, Halmos G, Arencibia JM \& Groot K. Complete regression of MX-1 human breast cancer xenografts after targeted chemotherapy with a cytotoxic analog of luteinizing hormone-releasing hormone, AN-207. Cancer 1999 (In Press).

61 Jungwirth A, Schally AV, Nagy A, Pinski J, Groot K, Galvan Get al. Regression of rat Dunning R-3327-H prostate carcinoma by treatment with targeted cytotoxic analog of luteinizing hormonereleasing hormone $\mathrm{AN}-207$ containing 2-pyrrolinodoxorubicin. International Journal of Oncology 199710 877-884.

62 Spindel ER, Giladi E, Segerson TP \& Nagalla S. Bombesin-like peptides: Of ligands and receptors. Recent Progress in Hormone Research 199348 365-391.

63 Cuttitta F, Carney DN, Mulshine JW, Moody TW, Fedorko J, Fischler A et al. Bombesin-like peptides can function as autocrine growth factors in human small cell lung cancer. Nature 1985 316 823-826.

64 Fathi Z, Corjay MH, Shapira H, Wada E, Benya R, Jensen R et al. BRS-3: A novel bombesin receptor subtype selectively expressed in testis and lung carcinoma cells. Journal of Biological Chemistry $19932685979-5984$.

65 Nagalla SR, Barry BJ, Creswick KC, Eden P, Taylor JT \& Spindel ER. Cloning of a receptor for amphibian $\left[\mathrm{Phe}^{13}\right]$ bombesin distinct from the receptor for gastrin-releasing peptide: Identification of a fourth bombesin receptor subtype (BB4). Proceedings of the National Academy of Sciences of the USA 199592 62056209.

66 Halmos G, Wittliff JL \& Schally AV. Characterization of bombesin/ gastrin-releasing peptide receptors in human breast cancer and their relationship to steroid receptor expression. Cancer Research 199555 280-287.

67 Yano T, Pinski J, Szepeshazi K, Halmos G, Radulovic S, Groot K et al. Inhibitory effect of bombesin/gastrin-releasing peptide (GRP) antagonist RC-3095 and LH-RH antagonist SB-75 on growth of MCF-7 MIII human breast cancer xenografts in athymic nude mice. Cancer 199473 1229-1238.

68 Schally AV. Hypothalamic hormones from neuroendocrinology to cancer therapy. Anticancer Drugs 19945 115-130.

69 Radulovic S, Cai R-Z, Serfozo P, Groot K, Redding TW, Pinski J \& Schally AV. Biological effects and receptor binding affinities of new pseudononapeptide bombesin/GRP receptor antagonists with N-terminal D-Trp or D-Tpi. International Journal of Peptide and Protein Research 199138 593-600.
70 Cai R-Z, Reile H, Armatis P \& Schally AV. Potent bombesin antagonists with $\mathrm{C}$-terminal Leu $\Psi\left(\mathrm{CH}_{2} \mathrm{~N}\right) \mathrm{Tac}-\mathrm{NH}_{2}$ or its derivatives. Proceedings of the National Academy of Sciences of the USA $19949112664-12668$.

71 Nagy A, Armatis P, Cai R-Z, Szepeshazi K, Halmos G \& Schally AV. Design, synthesis, and in vitro evaluation of cytotoxic analogs of bombesin-like peptides containing doxorubicin or its intensely potent derivative, 2-pyrrolinodoxorubicin. Proceedings of the National Academy of Sciences of the USA $199794652-656$.

72 Kiaris H, Schally AV, Nagy A \& Sun B. The cytotoxic bombesin analog AN-215 inhibits the growth of H-69 small cell lung carcinoma in vivo. Proceedings of $3 r d$ World Congress on Advances in Oncology and 1st International Symposium on Molecular Medicine, 15-17 October 1998, Crete, Greece. (Abstract).

73 Lamberts SWJ. The role of somatostatin and its analogs in the diagnosis and treatment of tumors. Endocrine Reviews 199112 450-482.

74 Schally AV. Oncological application of somatostatin analogues. Cancer Research 198848 6977-6985.

75 Bauer W, Briner U, Doepfner W, Haller R, Huguenin R, Marbach $\mathrm{P}$ et al. SMS-201-995: A very potent and selective octapeptide analogue of somatostatin with prolonged action. Life Sciences 198231 1133-1140.

76 Cai R-Z, Szöke B, Lu R, Fu D, Redding TW \& Schally AV. Synthesis and biological activity of highly potent octapeptide analogs of somatostatin. Proceedings of the National Academy of Sciences of the USA 198683 1896-1900.

77 Pollak MN \& Schally AV. Mechanisms of antineoplastic action of somatostatin analogs. Proceedings of the Society for Experimental Biology and Medicine 1998217 143-152.

78 Hofland LJ, Van Koetsveld PM, Waaijers M, Zuyderwijk J \& Lamberts SWJ. Relative potencies of the somatostatin analogs octreotide, BIM-23014, and RC-160 on the inhibition of hormone release by cultured human endocrine tumor cells and normal rat anterior pituitary cells. Endocrinology 1994134 301-306.

79 Reubi JC, Krenning EP, Lamberts SWJ \& Kvols L. In vitro detection of somatostatin receptors in human tumors. Metabolism 199241 (Suppl 2) 104-110.

80 Srkalovic G, Cai R-Z \& Schally AV. Evaluation of receptors for somatostatin in various tumors using different analogs. Journal of Clinical Endocrinology and Metabolism 199070 661-669.

81 Weckbecker G, Raulf F, Stolz B \& Bruns C. Somatostatin analogs for diagnosis and treatment of cancer. Pharmacology and Therapeutics $199360245-264$.

82 Reubi JC, Waser B, Foekens JA, Klijn JGM, Lamberts SWJ \& Laissue J. Somatostatin receptor incidence and distribution in breast cancer using receptor autoradiography: relation to EGF receptors. International Journal of Cancer 199046 416-420.

83 Reubi JC, Laissue J, Krenning E \& Lamberts SW. Somatostatin receptors in human cancer: Incidence, characteristics, functional correlates and clinical implications. Journal of Steroid Biochemistry and Molecular Biology 199243 27-35.

84 Bell GI \& Reisine T. Molecular biology of somatostatin receptors. Trends in Neuroscience $19931634-38$.

85 Patel YC, Greenwood MT, Panetta R, Hukovic N, Grigorakis S, Robertson LA et al. Molecular biology of somatostatin receptor subtypes. Metabolism 199645 (Suppl 1) 31-38.

86 Patel YC, Greenwood MT, Panetta R, Demchyshyn L, Niznik H \& Srikant CB. The somatostatin receptor family. Life Sciences 1995 57 1249-1265.

87 Schonbrunn A, Gu YZ, Dournard P, Beaudet A, Tannenbaum GS \& Brown PJ. Somatostatin receptor subtypes: Specific expression and signaling properties. Metabolism 199645 (Suppl 1) 8-11.

88 Reisine T \& Bell GI. Molecular biology of somatostatin receptors. Endocrine Reviews $199516427-442$.

89 Buscail L, Delesque N, Estève J-P, Saint-Laurent N, Prats H, Clerc P et al. Stimulation of tyrosine phosphatase and inhibition of cell proliferation by somatostatin analogues: Mediation by human somatostatin receptor subtypes SSTR1 and SSTR2. 
Proceedings of the National Academy of Sciences of the USA 199491 2315-2319.

90 Buscail L, Estève J-P, Saint-Laurent N, Bertrand V, Reisine T, O'Carroll A-M et al. Inhibition of cell proliferation by the somatostatin analogue RC-160 is mediated by SSTR2 and SSTR5 somatostatin receptor subtypes through different mechanisms. Proceedings of the National Academy of Sciences of the USA 199592 1580-1584.

91 Buscail L, Saint-Laurent N, Chastre E, Vaillant JC, Gespach C, Capella $\mathrm{G}$ et al. Loss of sst2 somatostatin receptor gene expression in human pancreatic and colorectal cancer. Cancer Research $1996561823-1827$.

92 Krenning EP, Kwekkeboom DJ, Bakker WH, Breeman WAP, Kooij PPM, Oei HY et al. Somatostatin receptor scintigraphy with ${ }^{[11}$ In-DTPA-D-Phe $\left.{ }^{1}\right]-$ and ${ }^{123}{ }^{12}-$ Tyr $\left.^{3}\right]$ octreotide: the Rotterdam experience with more than 1000 patients. European Journal of Nuclear Medicine 199320 716-730.

93 Otte A, Mueller-Brand J, Dellas S, Nitzsche EU, Herrmann R \& Maecke HR. Yttrium-90-labelled somatostatin-analogue for cancer treatment. Lancet $1998351417-418$.

94 Nagy A, Schally AV, Halmos G, Armatis P, Cai R-Z, Csernus Vet al. Synthesis and biological evaluation of cytotoxic analogs of somatostatin containing doxorubicin or its intensely potent derivative, 2-pyrrolinodoxorubicin. Proceedings of the National Academy of Sciences of the USA 199895 1794-1799.

95 Kahán Z, Nagy A, Schally AV, Hébert F, Sun B, Groot K et al. Inhibition of growth of MX-1, MCF-7 MIII and MDA-MB-231 human breast cancers after administration of targeted cytotoxic analog of somatostatin, AN-238. International Journal of Cancer 1999 (In Press).
96 Evans AA, Crook T, Laws SAM, Gough AC, Royle GT \& Primrose JN. Analysis of somatostatin receptor subtype mRNA expression in human breast cancer. British Journal of Cancer 199775 798-803. 97 Koppán M, Nagy A, Schally AV, Arencibia JM, Plonowski A, Halmos G et al. Targeted cytotoxic analogue of somatostatin AN-238 inhibits the growth of androgen-independent Dunning R-3327-AT-1 prostate cancer in rats at nontoxic doses. Cancer Research $1998584132-4137$.

98 Plonowski A, Schally AV, Nagy A, Sun B \& Szepeshazi K. Inhibition of PC-3 human androgen-independent prostate cancer and its metastases by cytotoxic somatostatin analog AN-238. Cancer Research 199959 1947-1953.

99 Szöke B, Horvath J, Halmos G, Rekasi Z, Groot K, Nagy A et al. LH-RH analogue carrying a cytotoxic radical is internalized by rat pituitary cells in vitro. Peptides 199415 359-366.

100 Tritton TR \& Yee G. The anticancer agent adriamycin can be actively cytotoxic without entering cells. Science $1982217248-$ 250.

101 Tritton TR. Cell surface actions of adriamycin. Pharmacology and Therapeutics 199149 293-309.

102 Kovács M, Schally AV, Nagy A. Koppán M \& Groot K. Recovery of pituitary function after treatment with a targeted cytotoxic analog of luteinizing hormone-releasing hormone. Proceedings of the National Academy of Sciences of the USA 199794 14201425 .

Received 30 October 1998

Accepted 12 February 1999 